\title{
Rapid identification of crustacean species by pcr amplification of the ribosomal internal transcribed spacer region (Its-I)
}

\begin{abstract}
The internal transcribed spacer 1 region (ITS-1) is located between the 18S and 5.8SrDNA nuclear genes and although it has been applied as a molecular marker for genetic identification, phylogeny and population studies in different organisms, it was only begun to be used in crustaceans in the last 15 years. The shrimp (Pleoticus muelleri) and the crab (Lithodes santolla) are two natural resources in Argentina of high commercial value with great demand in international markets (whole or processed). The Benthic Crustaceans INIDEP's Subprogram has initiated studies to promote artisanal and coastal fishing of the swimmer crab, Ovalipes trimaculatus (De Haan 1833), whose commercialization is based on cooked crab claws and pulp. In this framework, ITS- 1 assays were carried out to identify crustaceans species and provide a tool that could be used as a first approximation to authentication of fishery products. Results showed that the amplification of ITS- 1 has been effective in distinguishing crabs and swimmer crabs with simple visualization of their molecular weight band, $480 \mathrm{pb}$ and $650 \mathrm{bp}$, respectively. No amplification was achieved in shrimp under the same PCR conditions. The distinction of both species allowed, in addition, saving time and inputs as it did not need further treatment with restriction enzymes. This trial was the first attempt to authenticate fishery products and its optimization in other argentine crustaceans would serve as a tool for future traceability.
\end{abstract}

Keywords: crustacean, PCR, ITS, crabs, identification, traceability
Volume 2 Issue 5 - 2017

\author{
Trucco María Inés, Andreoli Gabriela \\ Instituto Nacional de Investigación y Desarrollo Pesquero, \\ Argentina
}

Correspondence: María Inés Trucco, Gabinete de Biología Molecular y Microbiología, Instituto Nacional de Investigación y Desarrollo Pesquero, Paseo Victoria Ocampo N ${ }^{\circ}$, Escollera Norte, B7602HSA Mar del Plata, Prov. Buenos Aires, Argentina, Tel +54 2234862586 intern 287, Email mtrucco@inidep.edu.ar

Received: October 03, 2017 | Published: December 07, 2017

\section{Introduction}

In eukaryotes, the first internal transcribed spacer 1 region (ITS-1) is located between the $18 \mathrm{~S}$ and 5.8S rDNA nuclear genes and although it has been applied as a molecular marker for genetic identification, ${ }^{1-3}$ phylogeny ${ }^{4,5}$ and population studies in different organisms, ${ }^{6-9}$ it began to be used only in the last 15years in crustaceans..$^{2,6,10,11}$ All of these studies have shown that ITS-1 is a robust molecular marker for the identification of organisms at the genus-species level and its popularity is due to the use of highly conserved primers; it is very variable and has a fast evolution rate. ${ }^{12}$ The shrimp (Pleoticus muelleri) and the crab (Lithodes santolla) are two natural resources in Argentina of high commercial value. The pleasant food texture and flavor of these species are features that have made them the target of great demand in international markets. Exportation of these fisheries (as whole or meat) in 2016 corresponded to $160.742 \mathrm{~T}$ and $1899 \mathrm{~T}$, respectively, mainly stationed to Spain, China, the United States, Japan, Vietnam and Italy, among others. ${ }^{13}$ On the other hand, in the Benthic Crustaceans Subprogram of INIDEP, studies were started to promote the artisanal and coastal fishing of the swimmer crab, Ovalipes trimaculatus, ${ }^{14,15}$ due to its high quality meat and excellent acceptance for affordable market prices. Its commercialization is based on cooked crab claws and pulp. ${ }^{16}$ It is necessary to develop analytical methods for the identification of species in order to detect and avoid unintentional or deliberate substitutions of fishery products, particularly when the product is not marketed as whole but manufactured or canned, losing in this process the morphological characteristics that it distinguishes (eg, exoskeleton). ${ }^{17}$ For this reason it was decided to carry out tests with the ITS- 1 as molecular marker to identify species with the aim of providing a tool that serves, not only to distinguish crustacean species, but also to be used as a first approach to authentication of fishery products or traceability.

\section{Materials and methods}

The CTAB technique, according to Milligan's protocol $5^{18}$ and phenol: chloroform: isoamyl alcohol method, according to Sam brook et al. ${ }^{19}$ were used for the extraction of total genomic DNA from shrimp, crab and swimmer crab muscles. The extracted DNA was resuspended in $100 \mu \mathrm{L}$ of ultrapure water and stored in freezer until use. Dilutions were standardized at 1:20 to obtain a working concentration of $15 \mathrm{ng}$ DNA $/ \mu \mathrm{L}$. The PCR reaction mixture $(15 \mu \mathrm{L}$ total volume) contained, in final concentration, 0.5units of Go Taq DNA polymerase (Promega), $1.2 \mathrm{mM} \mathrm{MgCl}, 0.3 \mu \mathrm{M}$ of each primer, $200 \mu \mathrm{M}$ each dNTP, and 15ng of genomic DNA. PCR amplification was performed in a temperature gradient thermo cycler programmed with a first denaturation step of $1 \mathrm{~min} 30 \mathrm{~s}$ at $94^{\circ} \mathrm{C}, 33$ cycles of $20 \mathrm{~s}$ at $94^{\circ} \mathrm{C}, 30 \mathrm{~s}$ at variable temperature from $56^{\circ}$ to $60^{\circ}$ and $30 \mathrm{~s}$ at $72^{\circ} \mathrm{C}$. At the end of these cycles, a final extension step was performed at $72^{\circ} \mathrm{C}$ for $5 \mathrm{~min}$ (to complete any partial amplification) and a final cooling at $6^{\circ} \mathrm{C}$. Negative controls were included in each amplification assay. The amplified product was electrophoresed with $0.5 \mathrm{X} \mathrm{TBE}$ as buffer medium at $60 \mathrm{~mA}$ on a $1.5 \%$ agarose gel with ethidium bromide $(0.5 \mathrm{mg} / \mathrm{mL})$. Gels were visualized and photographed under ultraviolet light and a $1 \mathrm{~Kb}$ molecular weight marker (Invitrogen) was used as a band size reference. The SP-1-58 (5'-CAC ACC GCC CGT CGC TAC TA-3 ') which is located in the 18S gene and SP-1-38 (5'-ATT TAG CTG CGG TCT TCA TC-3 '), located in 5.8SrDNA, were used as primers for ITS-1. The crab, shrimp and swimmer crab specimens used belong to the Molecular Biology and Microbiology 
Lab collection of different research campaigns carried out by the Crustaceans Fisheries Program.

\section{Results and discussion}

In this work the swimmer crab could be distinguish from the king crab L. Santolla simply by ITS- 1 fragment size. This fact is not usual in the ITS- 1 amplification that normally exhibits a single band for all the species studied and must be differentiated from each other after a subsequent treatment of the product with restriction enzymes. ${ }^{2,20}$ In the crab Ovalipes trimaculatus, PCR's product band was approximately $650 \mathrm{bp}$ while for $L$. santolla was $480 \mathrm{bp}$. There was no amplification band corresponding to shrimp (Figure 1). The same PCR conditions were repeated with other different dilutions and undiluted shrimp DNA, but with the same result, no amplification. Assays are now continued with this species as it is known that the same primers have worked in other shrimp species such as Penaeus japonicus, showing bands of 500 to $515 \mathrm{bp} .{ }^{6}$ This same molecular marker is currently been assayed in other Lithodidae such as the false southern king crab, Paralomis granulosa and in canned or manufactured products of the studied crustacean species.

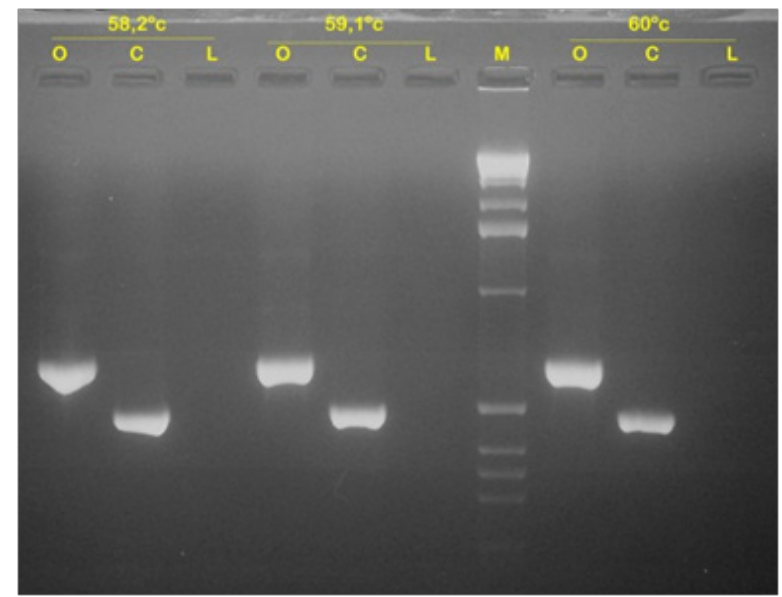

Figure I ITS-I amplification in swimmer crab Ovalipes trimaculatus (O), crab Lithodes santolla $(\mathrm{C})$ and shrimp Pleoticus muelleri $(\mathrm{L})$ with temperature gradient. (M), I kb molecular weight marker.

\section{Conclusion}

i. Amplification of the ribosomal DNA internal transcribed spacer 1 region (ITS-1) has been effective in crab (Lithodes santolla) and swimmer crab (Ovalipes trimaculatus) but not in shrimp (Pleoticus muelleri), with the same PCR conditions.

ii. The successful amplification of the ITS- 1 allowed the distinction between two genera of decapods such as the swimmer crab (Ovalipes trimaculatus) and the crab (Lithodes santolla), with bands of different molecular weight, $650 \mathrm{pb}$ and $480 \mathrm{pb}$, for each species. The exact length of each region will soon be confirmed by sequencing.

iii. The distinction of both species with rapid and simple visualization of its molecular weight also allowed saving time and inputs as no subsequent treatment with restriction enzymes was needed.

iv. This test constitutes the first approach to the authentication of fishery products in argentine crustaceans and would serve as a molecular tool for future traceability.

\section{Acknowledgements}

None.

\section{Conflict of interest}

Author declares that there is no conflict of interest.

\section{References}

1. Chow S, Ueno Y, Toyokawa M, et al. Preliminary analysis of length and GC content variation in the ribosomal first Internal Transcribed Spacer (ITS1) of marine animals. Mar Biotechnol. 2009;11(3):301-306.

2. Wu Z, Feng J, Chen J, et al. Phylogenetic analysis and species identification of popular shrimp species in southeast China using the first internally transcribed spacer of ribosomal DNA. Aquac Res. 2009;40(11):1251-1259.

3. Hong Js, Sekino M, Sato S. Molecular species diagnosis confirmed the occurrence of Kumamoto oyster Crassostrea sikamea in Korean waters. Fisheries Sci. 2012;78(2):259-267.

4. Coleman Aw, Vacquier Vd. Exploring the phylogenetic utility of ITS sequences for animals: a test case for abalone (Haliotis). $J$ Mol Evol. 2002;54(2):246-257.

5. Pérez Barros P, Damato ME, Guzman Nv, et al. Taxonomic status of two South American sympatric squat lobsters, Munida gregaria and Munida subrugosa (Crustacea: Decapoda: Galatheidae), challenged by DNA sequence information. Biol J Linn Soc. 2008;94(2):421-434.

6. Chu KH, Li CP, Ho HY. The first internal transcribed spacer (ITS-1) of ribosomal DNA as a molecular marker for phylogenetic and population analyses in Crustacea. Mar Biotechnol. 2001;3(4):355-361.

7. Ferrada S, Hernández K, Montoya R, et al. Estudio Poblacional del recurso anchoveta (Engraulis ringens Jenyns 1842) (Clupeiformes, Engraulidae), mediante analisis de ADN. Gayana. 2002;66(2):243-248.

8. Vierna J, Martínez Lage A, González Tizón Am. Analysis of ITS1 and ITS2 sequences in Ensis razor shells: suitability as molecular markers at the population and species levels, and evolution of these ribosomal DNA spacers. Genome. 2010;53(1):23-34.

9. Wood AR, Apte S, Macavoy ES, et al. A molecular phylogeny of the marine mussel genus Perna (Bivalvia: Mytilidae) based on nuclear (ITS1\&2) and mitochondrial (COI) DNA sequences. Mol Phylogenet Evol. 2007;44(2):685-698.

10. Harris DJ, Crandall KA. Intragenomic Variation Within ITS1 and ITS2 of Freshwater Crayfishes (Decapoda: Cambaridae): Implications for Phylogenetic and Microsatellite Studies. Mol Biol Evol. 2000;17(2):284-291.

11. Imai $\mathrm{H}$, Cheng JH, Hamasaki $\mathrm{K}$, et al. Identification of four mud crab species (genus Scylla) using ITS- 1 and 16S rDNA markers. Aquat Living Resour. 2004;17(01):31-34.

12. Aguilera Muñoz F, Valenzuela Muñoz V, Gallardo Escárate C. Authentication of commercial chilean mollusks using Ribosomal internal transcribed spacer (ITS) as Specie-specific DNA marker. Gayana. 2008; $72(2): 178-187$

13. Ministerio De Agroindustria, Subsecretaría De Pesca Y Acuicultura Exportaciones Pesqueras 2015: Comportamiento de los principales mercados 2015. Último acceso. 2016.

14. Bambill G, Lértora P. Pesca experimental del cangrejo nadador (Ovalipes trimaculatus). Inf. Camp. INIDEP No. 2015. p. 10.

15. Bambill G, Lértora P. Pesca experimental, con trampas, de cangrejo nadador (Ovalipes trimaculatus), zona Puerto Quequén. Provincia de Buenos Aires. Inf. Camp. INIDEP No. 2015. p. 6. 
16. Dima Jb. Procesamiento integral de las especies patagónicas de cangrejos marinos de valor comercial Ovalipes trimaculatus y Platyxanthus patagonicus. Tesis de Doctorado. Facultad de IngenierIa de la Universidad Nacional de La Plata, Argentina; 2013. p. 244.

17. Bossier P (1999) Authentication of seafood products by DNA patterns. J Food Sci 64(2):189-193.

18. Milligan BG. Plan DNA isolation. In: Hoezel AR, editor. Molecular genetic analysis of populations: an approach. USA; Oxford Univ Press: 1992. p. 59-86.
19. Sambrook J, Fritsch Ef, Maniatis T. Molecular cloning: A laboratory manual. Cold Spring Harbor Laboratory Press. 1989;61(1):17-18.

20. Fernández A, Garcia T, Asensio L, et al. PCR-RFLP Analysis of the Internal Transcribed Spacer (ITS) Region for Identification of 3 Clam Species. J Food Sci. 2001;66(5):657-661. 